\title{
Conservation Character Strengthening and its Impact in Kampung Pelangi
}

\author{
Tijan $^{1}$, Lolyta Andhika Puspa Wijaya ${ }^{2}$ \\ $\left\{\right.$ tijan@mail.unnes.ac.id $\left.{ }^{1}\right\}$ \\ ${ }^{1,2}$ Universitas Negeri Semarang, Indonesia, Indonesia
}

\begin{abstract}
Conservation character is a basic need to improve the condition of the nation today. It is consisting of three activities, namely protection, preservation, and sustainable use. This study aims to describe the conservation character strengthening program in Kampung Pelangi Semarang and its impact on the development of communities in the fields of education, social, cultural and economic. This study was conducted with a qualitative research method and interactive data analysis techniques. The results showed that the conservation character strengthening program in Kampung Pelangi was formed in three sequences: the decisions of citizens, the implementation of village development, and the habituation in everyday life. Three major impacts of the program were the change of residents' character from indifferent into willing to cooperate; economically providing employment opportunities through tourism programs; and change the community environment to be cleaner and beautiful. It is recommended that Kampung Pelangi to be a rule model for socio-cultural and conservation character improvements.
\end{abstract}

Keywords: Strengthening Character, Conservation, Social Care, Village Improvement.

\section{Introduction}

Character building is a fundamental requirement of a nation. Soekarno, one of Indonesia's founding fathers, has always reminded the importance of nation and character building [1]. The development of national character can be developed through education. Semarang State University was declaring itself as a Conservation-Based University in 2013. This policy was carried out institutionally and sustainably, namely: the development of Bio-edutainment Garden in 1990; work on planting a thousand trees in 2005; the development of Bioversity Garden in 2008; one man one tree movement in 2009; One Thousand Mangrove Planting in 2010; declaration of Semarang State University as a Conservation University in 2010; and the Vision of Semarang State University as Conservation and International Reputation University in 2013.

The environmental care (conservation) policy developed by Semarang State University has also been applied by the government of Semarang City, namely the development of Kampung Pelangi (Pelangi village). This conservation policy has changed Pelangi village from a slum village with indifferent people,to be a new favorable tourism destination Semarang.

In 1902, Theodore Roosevelt introduced the concept of conservation as an action to protect or preserve from destruction, loss, etc [2]. Conservation was also interpreted as preservation of cultural heritage [3]. Conservation is not only concerned with physical activities, but also includes a broad and universal value system, such as moral and social 
values [4]. Humans learn moral principles through their association with their social systems [5]. People are called to have moral or character by adjusting to rules that apply in his environment. One of the characters that must be maintained is conservation.

This study aims to describe: 1) steps of conservation character strengthening in Kampung Pelangi village; and 2) the impact on education, socio-culture, and economics in Kampung Pelangi. This research recommends other villages to imitate Kampung Pelangi in managing environmental and social cultural life. Furthermore, development of conservation character such as social care shall be included in the curriculum of primary, secondary and tertiary education.

\section{Research Methods}

This research used descriptive qualitative method. Descriptive qualitative method has been identified as important and appropriate for research questions focused on discovering the who, what, and where of events or experiences and on gaining insights from informants regarding a poorly understood phenomenon. Qualitative description is a suitable goal when a straight description of a phenomenon is desired or information is sought to develop and refine questionnaires or interventions [6]. The research was conducted in Kampung Pelangi, Semarang City, Indonesia. The focus of research is the conservation character strengthening programs. In addition, the study focused on identifying the impact of conservation character strengthening in education, social life, culture, and economic. Data are collected through observation, interviews, and documentation. Validity of data is analyzed through resources and techniques triangulation. The data was analyzed by interactive model through data collection, data reduction, data presentation, and conclusion.

\section{Results and Discussion}

\subsection{Conservation character Strengthening}

Kampung Pelangi is the new name of Randusari village. Randusari village is a slum area and steep hills with dense settlements in the middle of Semarang City. The idea of changing its name came from local community leaders to change the physical appearance and environment of the village from the seemingly dirty to look clean, beautiful, and attractive like a colorful rainbow.

The implementation of the change in the village was formed by the Kampung Pelangi Tourism Awareness Community (Pokdarwis). In order for the implementation of this policy to be effective and efficient then the Articles of Association and Bylaws were formulated. One of the prominent social changes after this policy was that the people of Kampung Pelangi did not mind if they had to clean their environment daily. They voluntarily and enthusiastically do routine community service weekly.

The fundamental change in Kampung Pelangi is improvement of conservation character. Character strengthening is a response to something that can increase the likelihood of repetition of this behavior. People of Kampung Pelangi experience an increase in the character of like to cooperate, be joking, caring (social, fellow, environment), like to have a discussion, and be generous. 
Kampung Pelangi residents improved their conservation character through the decision making process, the development of tourism villages, and the habituation in everyday life. Those proses followed grow and build strategy which was appropriate for developing tourism [7]. Kampung Pelangi activities can be described as improving the skills of the community to fill the job opportunities in the field of tourism, increasing the participation or involvement of the community in tourism activities, increasing the accessibility of tourism objects, and increasing the facilities and infrastructure of tourism.

Rachman stated that the indicators of conservation character are as follows: a) maintain cleanliness, beauty and preservation of nature; b) actively involved in community service; c) willing to do the task from the collective agreement; d) willing to help others without expecting a reward; e) not prioritizing personal and group interests rather than public interests; f) find ways to overcome differences of opinion or thoughts between yourself and others; $\mathrm{g}$ ) not indifferent to changes or environmental conditions [8]. These indicator can be seen in Kampung Pelangi.

\subsubsection{Cleanliness, Beauty, and Nature Conservation}

Kampung Pelangi is very clean, beautiful and natural. The residents hold cleaning every Sunday morning around 6 to 9 am, as stated in Article 4 of Pokdarwis 2017. They also preserves nature by planting hydroponic plants which were placed in front of houses and are often found on the river banks of Kampung Pelangi. Those maintaining environmental sustainability activities are indicators of environmental care [9]. The habituation of positive characters will broadly affect their village as future workplace. [10].

The conservation character of Kampung Pelangi residents is indeed ingrained. Kampung Pelangi is indeed an example of other village or village communities to preserve nature, even without special program from the government. The residents initiated the idea and proposed a policy to the government which now changed their village name to Kampung Pelangi. The existence of a clean, neat and beautiful environment makes people and tourists enthusiastic and feel comfortable to come and live in Kampung Pelangi.

\subsubsection{Residents are Actively Involved in Working Around the Neighborhood}

Kampung Pelangi residents are very well-known as people who like to work together and very active in working around the environment, as stated in Article 6 of Pokdarwis 2017. Work devotion is an attitude that is able to work well together of something and want to develop their potential and unselfish. Attitude of actively cooperate in voluntary work for environment indicates that the residents are very concerned about the environment and each other. Painting the walls and houses, Paint treatments, and paving renovation programs are carried out jointly by the people of Kampung Pelangi.

\subsubsection{Citizen Out Obligations in Accordance with Collective Agreements}

In Kampung Pelangi, there is an organization called Tourism Awareness Community (Pokdarwis). This social community is a form of society which responsible for Kampung Pelangi. They give orders, invitations, appeals, as well as encouragement to the people of Kampung Pelangi by volunteering for the good of the Kampung Pelangi on the basis of mutual agreement. The attitude of being willing to do the task in accordance with the collective agreement is an altruistic act. Berkowitz and Krebs defined that being willing to do a task 
according to an agreement or altruism as all behaviors intended to be full of willingness, must provide benefits to others and must help or do something without hoping to be repaid [11].

Those activities are in accordance with the Regulation of the Minister of Tourism of the Republic of Indonesia Number 14 Year 2016 about Guidelines for Sustainable Tourism Destinations and Pokdarwis's articles 1 and 7 in 2017. Pokdarwis gave direction to the neighborhood leaders which would later be disseminated to the residents of Kampung Pelangi. So that the neighborhood leaders have same roles and tasks as Pokdarwis.

\subsubsection{Willing to Help Other People without Expecting Rewards}

The attitude of being willing to help others is shown in everyday life. This is in line with Leeds' view, that whatever released is merely volunteerism [11]. The Kampung Pelangi residents volunteered to help their neighbors when they were in trouble or in need. This is evidenced when landslides occur in the upper areas that are prone to landslides. The society voluntarily help to get rid of and raising the stone from victims' home without expecting any reward.

\subsubsection{Not Prioritizing Personal and Group Interests}

The attitude of giving priority to obligations rather than rights is a value of conservation character. This value serves as a guide in understanding the reality of everyday problems. The Kampung Pelangi residents consciously prioritize the interests of the group in helping disadvantaged people. In accordance with the agreement in the Kampung Pelangi article 5 of Pokdarwis 2017, that Pokdarwis seeks the welfare of its members. Pokdarwis held some social activities such as delivering grants, providing educational scholarships, and sharing foods for the poor and orphans. Those showed a high level of altruistic.

\subsubsection{Not Indifferent Against Environmental Conditions}

Not being ignorant of changes or environmental conditions is called love of the environment. This means a way of thinking, attitudes and actions of someone who shows loyalty, awareness and a high appreciation of language, physical and social environment, culture, economy, and politics of his region. This as an indicator of caring for institutions, namely carrying out tasks properly according to institutional priorities [9]. Kampung Pelangi's community is caring and not ignorant about the changes in Kampung Pelangi.

\subsection{Impact of Conservation Character Strengthening}

People are more oriented towards conservation provided alternative livelihood opportunities are available [12]. The conservation character strengthening in Kampung Pelangi has increased the residents social awarness. According to local community leaders, helping each other has become their habit. Increasing social awareness can reduces social inequality and bring peace to society.

\subsubsection{Economic Impact}

The existence of the Kampung Pelangi Program has progressed to the level of the economy of each family. This agreement is stated in Article 6 of Pokdarwis 2017. Viral news 
about Kampung Pelangi encourages tourists and visitors to have a visit. The residents earn their living by offering tourists with various souvenir items, culinary, and photography.

Many of residents did not have a House Ownership Certificates. After conducting Kampung Pelangi program, there were 349 House Ownership Certificates obtained from the City Government. Previously, many residents were unemployed. Currently, many of them work and supplement their income. The unemployed was lifted out of poverty by setting up a stall in front of his house.

\subsubsection{Social Impact}

The Kampung Pelangi community provides donations for orphans. There are also social activities for cheap groceries, Friday blessings, and educational scholarships. This showed that citizens have trust and commitment to the institution's vision and mission.

Kampung Pelangi holds contests and events, such as fishing competitions conducted with the participation of outside communities. The fishing competition was supported by the Fisheries Service and was held in Semarang River in front of the Kampung Pelangi. Subagyo said that indicators of institutional care are proactive, effective, and efficient in building a societal institution systems [9]. Up to now, there is no one make a written regulations regarding the conservation character in Kampung Pelangi. They only promote the value of tourism as well as those with oral encouragement of one another.

\subsubsection{Environmental Impact}

The residents' respects of cleanliness can be seen by holding a garbage bank, distributing hydroponic seeds, and working devote regularly to cleaning the yard every morning and evening. It's accorded to the aim of Thematic Village Program, such as utilizing local wisdom in managing potential and solve environmental problems. The environment is kept clean, so that the image and good name of Kampung Pelangi are maintained. It is expected that the tourists, when returning from their visit, will socialize and want to return to Kampung Pelangi which is famous for its unique and clean.

\subsubsection{Psychological Impact}

The community has transformed the indifferent character to be people who have willingness to cooperate. Harmony between community members is well-established, honed, compassionate, and fostered. The community becomes more loyal and responsible for maintaining the good name of Kampung Pelangi. In a number of alleys, many of which were drunk. Now, the alleys are deserted and no more drunk. The community regularly hold gatherings and meetings.

\subsubsection{Educational Impact}

Residents becomes more creative. They can make crafts, paintings, and bouquet. Residents can sell their crafts at flower shops. Kampung Pelangi is crowded and colorful. The agreement to be creative is stated in Article 8 of Pokdarwis 2017. The aim are to organize various businesses related to the development of various potentials in the field of tourism at the local level and to encourage the implementation of events to appreciate and promote tourism potential in the surrounding environment. 


\section{Conclusion}

In general, it can be concluded that the government program in enhancing the conservation character in Kampung Pelangi was very successful. Thus, Kampung Pelangi has improvement in social, economic, environmental, psychological, and educational. First, the conservation character strengthening program in Kampung Pelangi Semarang was implemented through the planning, implementation, and habituation. At the planning stage, community leaders discuss about environmental issues. At the program implementation stage, the community actively participates in painting when mass painting is held, diligently cleaning the house and yard around the house, and actively working. Thus, the harmony of the community is well established, where residents are getting more and more loyal. As for the habituation stage, community leaders and the government gave appeals and socialization to preserve the character of conservation character. So, the residents are caring the village with full awareness and responsibility.

Second, the impacts of conservation character strengthening programs are: 1) social impacts, change of indifferent character to be willing to cooperate; 2) economic impact, improvement of the economy of each family, where many people got a job and gained more income by making crafts and the Flower Market increasingly crowded; and 3) environmental impacts, the community maintains cleanliness, beauty and nature preservation, and is actively involved in preserving its surrounding environment .

\section{References}

[1] Handoyo E, Tijan. Model Pendidikan Berbasis Konservasi Pengalaman Universitas Negeri Semarang. Semarang: Cipta Prima Nusantara; 2010.

[2] Margarea et al. Universitas Negeri Semarang Universitas Konservasi. Semarang: UNNES Press; 2010.

[3] Keesing RM. Antropologi Budaya Suatu Perspektif Kontemporer Edisi 2 Jilid 1. Jakarta: Erlangga; 1999.

[4] Sudarmin S, Mursiti S, Asih AG, Hikmah N, Yamtinah S. Increasing character value and conservation behavior through integrated ethnoscience chemistry in chemistry learning: A Case Study in The Department of Science Universitas Negeri Increasing character value and conservation behavior through integrated ethnoscience chemistry in chemistry learning: A Case Study in The Department of Science Universitas Negeri Semarang . 2018. doi:10.1088/1757-899X/349/1/012061.

[5] Souryal SS. Etika dalam Peradilan Pidana Upaya Mencari Kebenaran. Saduran Jend. Pol. (Purn.) Koenarto. Jakarta: Cipta Manunggal; 1999.

[6] Kim H, Sefcik JS, Bradway C. Characteristics of Qualitative Descriptive Studies: A Systematic Review. Res Nurs Heal 2017;40:23-42. doi:10.1002/nur.21768.

[7] Sutedjo A, Prasetyo K, Sudaryono L. Condition of karangkepatihan village community balong district ponorogo regency in supporting development of community based tourism Condition of karangkepatihan village community balong district ponorogo regency in supporting development of community bas 2018.

[8] Rachman M. Konservasi Nilai dan Warisan Budaya. Indones J Conserv 2012;1.

[9] Subagyo D. Buku Panduan FIS Peduli Menguatkan Konservasi Sosial. Semarang: Fakultas Ilmu Sosial; 2015. 
[10] Parmin. The Character Building of Prospective Science Teachers Through A Conservation Coaching The Character Building of Prospective Science Teachers Through A Conservation Coaching 2019. doi:10.1088/1742-6596/1155/1/012067.

[11] Alma B. Pembelajaran Studi Sosial. Bandung: Alfabeta; 2015.

[12] Suwarno E, Suhesti E. Village Conservation Program: Community Readiness Assessment and Strategies Arrangement Village Conservation Program : Community Readiness Assessment and Strategies Arrangement n.d. 